\title{
Wpływ reformy administracyjnej na tożsamość terytorialną mieszkańców północno-wschodniej Polski \\ The impact of administrative reform on the territorial identity of inhabitants of north-eastern Poland
}

\author{
Michał Konopski $\odot$ Rafał Wiśniewski \\ Instytut Geografii i Przestrzennego Zagospodarowania im. Stanisława Leszczyckiego PAN \\ ul. Twarda 51/55, 00-818 Warszawa \\ konopski@twarda.pan.pl•rafwis@twarda.pan.pl
}

Zarys treści. Obecny podział administracyjny Polski opiera się w znacznym stopniu o granice narzucone, które dzielą niegdyś spójne regiony. Nowe jednostki administracyjne cechują się znacznym brakiem spójności z ich zasięgiem przestrzennym. W świadomości społecznej nadal funkcjonują jednak granice reliktowe będące wypadkową uwarunkowań historycznych. Problem badawczy wynika z dychotomii między nazwami (toponimią) nadanymi województwom wskutek reformy administracyjnej z roku 1999 a nazwami regionów historycznych. Artykuł przedstawia wybrane wyniki badań empirycznych przeprowadzonych z zastosowaniem kwestionariusza ankiety wśród mieszkańców 71 gmin północno-wschodniej Polski. Nadrzędnym celem pracy było zbadanie wpływu ostatniej reformy administracyjnej na tożsamość regionalną badanej społeczności, ze szczególnym uwzględnieniem Podlasia jako regionu przygranicznego o dużym stopniu zróżnicowania językowego, kulturowego i wyznaniowego. Określono poziom identyfikowania się ankietowanych z różnymi szczeblami i kategoriami podziału przestrzennego. Respondenci silniej identyfikują się z poziomem krajowym (narodowym) i lokalnym (małe ojczyzny) niż z regionalnym, który stanowi dopiero trzeci szczebel w hierarchii poczucia tożsamości z danym obszarem. Tożsamość regionalna ludności zamieszkującej badany obszar budowana jest przede wszystkim w oparciu o współczesne granice regionów administracyjnych.

Słowa kluczowe: region administracyjny, region historyczny, granica, tożsamość terytorialna, pogranicze, Podlasie.

\section{Wstęp}

Współczesne granice państwowe mają dwojaki charakter. Z jednej strony nadal pełnią pierwotną funkcję oddzielając od siebie terytoria państw. Bardzo często podziały te nie ograniczają się jedynie do funkcji czysto formalnej, ale przybierają formę bariery przestrzennej (np. wschodnia granica Polski będąca jednocześnie granicą Unii Europejskiej). Jest też inne postrzeganie współczesnych granic, szczególnie tam, gdzie mamy do czynienia z integracją terytorialną (np. strefa Schengen). Wprawdzie formalna granica nadal pozostaje, jednak nie stanowiąc istotnej bariery jest strefą kontaktu ułatwiającą przepływ idei, towarów, ludzi itp. (Ratti, 1993).

Istnienie granic, zarówno tych stanowiących bariery, jak i będących czynnikiem pobudzającym współpracę oraz trwałość tych granic ma wieloaspektowe oddziaływanie: 
od ekonomicznego (handel przygraniczny, wymiana handlowa na poziomie międzynarodowym) (Komornicki, 2010; Powęska, 2011) i społecznego (np. w sferze edukacyjnej) (Palmowski, 2007) po niematerialny aspekt przejawiający się m.in. kształtowaniem się w obrębie danego terytorium poczucia pewnej wspólnoty i przywiązania do danego obszaru. Pojawianie się lub zanikanie granic państwowych, jak również granic wewnętrznych jednostek administracyjnych może wpływać na przemiany poziomu tożsamości (Erikson, 1974; Huntington, 1998; Scott, 2018). Co więcej, zmiany granic modyfikują siłę przywiązania do różnych poziomów przestrzennych, także regionalnych (Weigend, 1950; Miszczuk, 2003; Rykiel, 2010; Zaborowski, 2013). Pierwotne tożsamości terytorialne ulegają osłabieniu, tworzą się zaś nowe, nacechowane odmiennym postrzeganiem granic, wartości i symboliki (np. wpływ utworzenia województwa bielskiego w 1975 r. i wynikający z niego wzrost regiocentryzmu administracyjnego - Matykowski, 2017). Ewolucja granic regionów i państw jest zjawiskiem naturalnym. Podobnie, powiązana z danym obszarem świadomość istnienia wspólnego terytorium nie jest dana raz na zawsze (Rykiel, 1985). Co więcej, bardzo często nowe granice powstawały wtórnie do zagospodarowania przestrzennego danego obszaru (granice subsekwentne) (Hartshorne, 1936). Dzieliły one nie tylko istniejące układy gospodarcze, ale separowały również wcześniej ukształtowane wspólnoty kulturowe. Dalszy rozwój kulturowy i tożsamościowy tych wspólnot zależał m.in. od polityki danego państwa względem zajętego terytorium i zamieszkującej go ludności.

Nie tylko granice państwowe kształtują poziom tożsamości ludności zamieszkującej dane terytorium. Regionalny poziom tożsamości kształtowany jest także przez wewnętrzne podziały administracyjne. Również w tym przypadku trwałość tych podziałów ma istotne znaczenie dla konstytuowania się emocjonalnych więzi z danym regionem. W okresie średniowiecza i I Rzeczpospolitej regiony administracyjne cechowały się dużą stabilnością granic (Solarz, 2014). W przypadku większości województw nie zmieniały się przez stulecia, aż do rozbiorów pod koniec XVIII w. Trwałość granic (obecnie historycznych lub reliktowych) przyczyniła się do wykształcenia silnej w porównaniu do czasów współczesnych tożsamości regionalnej zamieszkujących je społeczności małych ojczyzn (Sobczyński, 1984). Nie bez znaczenia były również niska mobilność mieszkańców wynikająca z niedorozwoju sieci komunikacyjnej oraz powiązana z nią znaczna izolacja przestrzenna. Od czasów rozbicia państwa Rzeczpospolitej wielokrotnie zmieniano granice oraz podziały administracyjne zaborczych mocarstw, przesuwano granice państwowe i wojewódzkie. Po II wojnie światowej reformę administracyjną w Polsce przeprowadzano średnio co 25 lat. Jest to relatywnie krótki okres na wykształcenie więzi społeczności z danym regionem administracyjnym, identyfikowania się z nim czy tworzenia tożsamości regionalnej. Obecnie w naszym kraju żyją równolegle co najmniej trzy pokolenia, które dorastały w odmiennych podziałach terytorialnych Polski z 17 (w latach 1950-1975), 49 (1975-1998) oraz 16 województwami (od roku 1999).

Istota problemu badawczego wynika z dychotomii między nazwami (toponimią) nadanymi województwom wskutek reformy administracyjnej z roku 1999 a nazwami regionów historycznych. Granice nowych jednostek administracyjnych cechują się znacznym brakiem spójności z zasięgiem krain historycznych (m.in. Miszczuk, 2003; Zaborowski, 2013). Można więc przyjąć, że granice współczesnych województw stanowią swego rodzaju granice narzucone, które obecnie dzielą niegdyś spójne regiony. Z drugiej strony, w Polsce nadal w świadomości społecznej funkcjonują granice reliktowe będące wypadkową uwarunkowań historycznych, granic dawnych dzielnic piastowskich czy zaborów. Granice 
te są do dziś zauważalne na przykład w zróżnicowaniu preferencji wyborczych, struktury osadnictwa, sytuacji demograficznej, użytkowania ziemi, krajobrazu kulturowego, itd.

Uwzględniając powyższe kwestie, głównym celem artykułu jest analiza wpływu ostatniej reformy administracyjnej (z 1 stycznia 1999 r.) na tożsamość regionalną mieszkańców północno-wschodniej Polski, ze szczególnym uwzględnieniem Podlasia jako regionu przygranicznego o dużym stopniu zróżnicowania językowego, kulturowego i wyznaniowego. Ponadto określony zostanie poziom identyfikowania się ankietowanych z różnymi szczeblami i kategoriami podziału przestrzennego, uwzględniając współczesne i historyczne granice jednostek administracyjnych, makroregionów fizyczno-geograficznych, itd.

\section{Tożsamość terytorialna a granice administracyjne}

Świadomość regionalna jako stan świadomości społecznej wyznaczający tożsamość regionalną jest według Z. Chojnickiego (1996) immanentnym elementem w krystalizacji przestrzenno-materialnej regionu. Świadomość tę tworzą charakter i kształt regionu (a więc także granice) oraz jego wartościowanie i symbolika. Wymiarem świadomości regionalnej są wyobrażenia przestrzenne o regionie, które mogą odnosić się do układów: liniowych (np. granic), powierzchniowych (np. jednostek podziału administracyjnego, w pełni lub częściowo należących do regionu) oraz punktowych (np. najważniejszych miast regionu) (Matykowski, 1996). Istotnym wymiarem samookreślenia społeczności i krystalizacji przestrzenno-funkcjonalnej regionu jest jego zdefiniowanie terytorialne w sposób formalny lub nieformalny (Whebell, 1973). Definiowanie to odbywa się m.in. poprzez nadawanie regionowi mian stosując endoetnonimy czyli nazw, za pomocą których społeczność określa własne terytorium zamieszkania lub egzoetnonimy - określenia stosowane przez ludność spoza jego granic. Budowanie tożsamości regionalnej i krystalizacja przestrzenno-materialna regionu wiąże się także ściśle z delimitacją jego granic (Matykowski, 2017). Może być ona oparta na założeniach i kryteriach subiektywnych lub wynikać z realnie wyodrębniającej się z otoczenia jednostki przestrzennej (Miszczuk, 2003). Regionalizacja administracyjna jest zatem formalizacją regionu naturalnego lub sztucznego (antropogenicznego).

Pojęcie tożsamości ma charakter polimorficzny i niejednoznaczny, obarczone jest więc znaczną dozą subiektywizmu. Według Z. Bokszańskiego $(1989$, s. 6) „tożsamość jednostki wydaje się niezbędnym, a może nawet zasadniczym narzędziem pojęciowym w analizie sytuacji człowieka w społeczeństwie współczesnym i próbach wyjaśnienia bądź zrozumienia kluczowych fenomenów społecznych naszych czasów". Przedmiotem podjętych badań jest tożsamość społeczna, a więc zbiorowa, zwielokrotniona tożsamość indywidualna, ukształtowana na podstawie wspólnego systemu aksjo-normatywnego (powiązanego funkcjonalnie zespołu norm i wartości dotyczących wszelakich przejawów życia społecznego, charakterystycznego dla określonej kultury, regulujących życie społeczeństwa i życie jednostki społecznej) (Bokszański, 2005). Tożsamość społeczna odnosi się do cech przypisywanych jednostce przez innych (Giddens, 2005) bardziej niż do obrazu samego siebie, jednostka uświadamia sobie zatem własną tożsamość i odczuwa ją (Rykiel, 2010), co stanowić może z kolei źródło autoidentyfikacji. Kluczowym czynnikiem wspomagającym tożsamość społeczną jest pamięć zbiorowa. Stanowi ona tworzywo świadomości posiadania wspólnej przeszłości. Pamięć zbiorowa odpowiada za przekazywanie wartości kulturowych, w tym języka, przełomowych wydarzeń, obyczajów, itd. (Malicki, 2010). Tożsamość 
budowana na pamięci zbiorowej, jest silnie ugruntowana w przeszłości i ma większe zdolności aby przetrwać zmiany terytorialne jak tworzenie nowych granic państwowych czy regionalnych. Polacy bez podtrzymywania pamięci zbiorowej o swojej historii, kulturze i tradycji nie podjęliby wysiłku w dążeniach do odzyskania niepodległości po ponad wieku bytowania w granicach trzech państw zaborczych. Regionalna pamięć zbiorowa także dziś opiera się często zmieniającym się podziałom administracyjnym. Granice historyczne i reliktowe nadal zamykają terytoria niesformalizowane, wyróżniające się specyficznym krajobrazem kulturowym.

Tożsamość terytorialna występować może w różnych skalach przestrzennych. Z. Rykiel (1999) wyróżnia pięć szczebli hierarchicznych tożsamości: elementarny (dom, rodzina), lokalny (sąsiedztwo, dzielnica), regionalny (region, zbiorowość regionalna), narodowy (kraj, naród) i ponadnarodowy (np. Europa, Unia Europejska). Można zatem mówić o tożsamości narodowej, regionalnej, lokalnej, miejskiej, itd. (Rykiel, 2016). Współzależność między tożsamością a terytorium jest przedmiotem zainteresowania geografów od lat 70. XX w. Prowadzone były badania empiryczne z wykorzystaniem różnych metod, np. map mentalnych (Jordan, 1978). Analizowano tożsamość w odniesieniu do jednostek administracyjnych (Knight, 1982; Veneri, 2011). Podjęto również badania nad tożsamością terytorialną w kontekście generowania i ukierunkowania przez nią procesów terytorializacji, która sama w sobie wzmacnia proces identyfikacji między społecznością a zamieszkiwaną przestrzenią (Pollice, 2003). W ujęciu regionalnym badania nad tożsamością terytorialną prowadzone w polskim środowisku naukowym dotyczyły m.in. Górnego Śląska (Rykiel, 1985), Dolnego Śląska (Rak, 2013), regionu poznańskiego (Matykowski, 1996), Warmii (Szyfer, 1996), Wielkopolski (Schmidt, 1997), Małopolski (Prawelska-Skrzypek, 1996), Mazur (Łukowski, 2002), Podlasia (Barwiński, 2004) oraz Lubelszczyzny (Dziekanowska, 2015). Badano także wpływ przebiegu granic województw na tożsamość regionalną oraz postrzeganie regionów Małopolski i Śląska (Nowak, 2018). W powyższych badaniach często wykazywano relatywnie niskie utożsamianie się z poziomem regionalnym w stosunku do państwowego czy lokalnego. Uwarunkowania historyczne, w jakich znajdowała się Polska na przełomie XIX i XX w. nie sprzyjały bowiem kształtowaniu się poczucia przynależności regionalnej (Matykowski, 2017).

Podział terytorialny stanowi jeden z wyznaczników „siły administracyjnej” państwa (Giddens, 1985). Regionalizacja administracyjna jest kształtowana przez szereg uwarunkowań, do których zaliczyć można m.in. położenie geopolityczne, walory środowiskowe, poziom rozwoju ekonomicznego, potencjał demograficzny, zróżnicowanie etniczno-kulturowe i inne (zależne od danego państwa). Mnogość uwarunkowań i ich zróżnicowanie powoduje, że uniwersalny model podziału terytorialnego państwa nie istnieje (Pezzini, 2000). W okresie I Rzeczpospolitej podział administracyjny był w głównej mierze uwarunkowany strukturami kościelnymi oraz granicami dawnych dzielnic piastowskich. Z kolei w okresie PRL-u koncepcje podziału administracyjnego oparte były przede wszystkim na kryterium ekonomicznym (Miszczuk, 2003). W dobie transformacji ustrojowej Polski, naukowcy zwracali uwagę na potrzebę, aby nowy podział terytorialny opierał się na racjonalnych i obiektywnych założeniach (m.in. Kołodziejski, 1991; Szczepkowski, 1991). Świadomość regionalną - jako jedno z uwarunkowań historycznych - uwzględniano w roli istotnego kryterium podziału administracyjnego. Wagę uwarunkowań historycznych w transformujących się państwach Europy Środkowo-Wschodniej podkreślali m.in. R. Schattkowsky (1996), I. Geiss (1996) czy T. Otremba (1997). Ostatnia reforma admi- 
nistracyjna nie uwzględniła jednak uwarunkowań historycznych w przypadku przebiegu wielu granic województw. Brak konsekwencji zauważyć można także w nazewnictwie nowopowstałych jednostek administracyjnych, z których część pochodzi od regionów historycznych (np. podlaskie, pomorskie, wielkopolskie), a niektóre od nazwy miast stołecznych (np. łódzkie, lubelskie, opolskie). W przypadku województwa podkarpackiego toponim pojawił się dopiero wskutek reformy (Rykiel, 2009). Granice współczesnych województw nie są spójne z granicami regionów historycznych (Miszczuk, 2003; Zaborowski, 2013; Nowak, 2018.) Obecny podział administracyjny kraju, który w swoich założeniach dostosowuje Polskę do zasad regionalizacji stosowanej w Unii Europejskiej był krytykowany jeszcze zanim zaczął obowiązywać w 1999 r. Obowiązujący podział odbiega od wszelkich koncepcji przedstawianych przez środowisko naukowe (Miszczuk, 2003), wskazujące również potrzebę korekty tego podziału (np. Zaborowski, 2013).

\section{Metoda badawcza i charakterystyka respondentów}

W artykule wykorzystano wyniki badań ankietowych przeprowadzonych w 71 gminach województwa podlaskiego, mazowieckiego, lubelskiego i warmińsko-mazurskiego. Głównym kryterium doboru gmin było ich położenie względem analizowanych granic administracyjnych (obecnych i historycznych) tj.:

1. granic pierwszego województwa podlaskiego z czasów I Rzeczpospolitej z lat 1569-1795, tzw. historycznego Podlasia (to kryterium spełnia 30 gmin);

2. wspólnych granic departamentu siedleckiego (1810-1815), województwa podlaskiego (1816-1837) guberni podlaskiej - zwanej podlaską (1837-1844) oraz siedleckiej (1867-1912) (20 gmin);

3. granic województw północno-wschodniej Polski według podziału administracyjnego z lat 1975-1998 (wewnątrz których badana społeczność potencjalnie cechuje się tożsamością podlaską, tj. województwa bialskopodlaskie, białostockie i siedleckie) (42 gminy);

4. granic współczesnego województwa podlaskiego (26 gmin).

Ponadto, 8 z 71 gmin cechuje brak położenia przy jakiekolwiek z przedstawiony granic.

Badania kwestionariuszowe ${ }^{1}$ przeprowadzono w gminach wiejskich i miejsko-wiejskich przylegających do wymienionych granic jednostek administracyjnych. Wyznaczono pary gmin po wewnętrznej i zewnętrznej stronie granicy, zakładając podobną liczbę gmin po obu jej stronach. Kryterium dodatkowym było uwzględnienie kilku gmin niesąsiadujących z granicami województw. Celem takiego podejścia było scharakteryzowanie tożsamości terytorialnej społeczności żyjących w oddaleniu od granic regionów admini-

${ }^{1}$ Kwestionariusze ankiety wysłano do szkół podstawowych i/lub gimnazjów w siedzibach gmin. Za pośrednictwem uczniów ankiety skierowane zostały do pełnoletnich respondentów (rodziców lub opiekunów prawnych uczniów oraz pozostałych domowników). Badania pilotażowe pozwoliły na wybór optymalnego wariantu przeprowadzenia zasadniczych badań ankietowych oraz kalibrację narzędzia badawczego. W okresie 17.02.2017 - 10.01.2018 wysłano ogółem 19540 ankiet do 73 szkół, z których 20 znajduje się w województwie lubelskim, 18 w mazowieckim, 31 w podlaskim oraz 4 w warmińsko-mazurskim. Otrzymano 9537 ankiet z 71 gmin. Stopa zwrotu wyniosła 48,81\%. Zaletą takiej metody jest możliwość dotarcia do dużej liczby respondentów, natomiast jej wadą ograniczenie próby badawczej do osób mających dzieci w wieku szkolnym, co determinuje wiek respondentów do przedziału od ok. 30 do ok. 50 lat. 
stracyjnych. Analiza objęła jedynie gminy wiejskie i miejsko-wiejskie zakładając, że cechują się najwyższym udziałem ludności zasiedziałej o ugruntowanej tożsamości terytorialnej.

W strukturze próby badawczej zdecydowanie przeważają kobiety $(70,1 \%)$. Najliczniej reprezentowaną grupą wiekową respondentów jest przedział 30-39 lat (43,7\%). Znaczący jest również udział grupy 40-49 lat (38,4\%), zaś pozostałe grupy wiekowe reprezentowane są mniej licznie, kolejno 50-59 lat (9,0\%), 60 i powyżej (4,6\%) oraz 18-20 lat (4,3\%). Na uwagę zasługuje fakt, że większość respondentów w przeważającej części swojego świadomego życia funkcjonuje w obecnym podziale administracyjnym, co jest nie bez znaczenia dla wyników badań. Większość respondentów $(61,8 \%)$ urodziła się w gminie, w której zostały przeprowadzone badania. Ich stopień zakorzenienia oraz wiedza na temat przodków zamieszkujących gminę są zróżnicowane. Struktura wyznaniowa respondentów cechuje się dominacją rzymskich katolików (93,9\%). Prawosławni stanowili niewielki udział badanych $(4,5 \%)$ i jedynie w trzech ankietowanych gminach byli w większości, tj. Czyże $(88,3 \%)$ i Narewka $(71,2 \%)$ znajdujących się w powiecie hajnowskim oraz gminie Mielnik (54,0\%) położonej w powiecie siemiatyckim. Przeważająca część respondentów (90,9\%) identyfikuje się wyłącznie z narodowością polską. Pozostałe najliczniej reprezentowane narodowości to Litwini (Puńsk - 76,8\% ankietowanych) oraz Białorusini (gminy Czyże $37,8 \%$ i Narewka - 21,7\%) i Ukraińcy (10,9\% respondentów w gminie Sawin położonej powiecie chełmskim). Szczególnie we wschodnich gminach obszaru badań istotny był udział ankietowanych (często powyżej 1/3 odpowiedzi) niedeklarujących żadnej przynależności narodowej, lecz określających się jako „tutejsi”. Odsetek takich respondentów jest najwyższy w gminach o przewadze ludności wyznania prawosławnego, zwłaszcza w dwóch najstarszych przedziałach wiekowych.

\section{Charakterystyka obszaru badań}

Obszar badań obejmuje północno-wschodnią Polskę, pod wieloma względami wyjątkową część kraju. Od stuleci były to tereny ścierania się wielu kultur i wpływów politycznych. Wskutek przenikania się kręgów cywilizacyjnych Wschodu i Zachodu, jest to obszar pogranicza narodowo-etnicznego i religijnego. Koegzystowali tu ze sobą osadnicy z Rusi, Mazowsza, Jaćwieży i Litwy, a także Żydzi i Tatarzy. Przeważającą część obszaru badań stanowi Podlasie. Już w samym toponimie regionu odnaleźć można określenie pogranicza. Według najbardziej prawdopodobnej hipotezy, nazwa regionu pochodzi od krainy położonej „pod Lachami" (Polakami) czyli przy granicy z Polską (Gloger, 1918). Przeszłość historyczna Podlasia przyczyniła się do jego zróżnicowania narodowościowego, religijnego, językowego i w efekcie - kulturowego. Obecnie jest to jeden z najbardziej zróżnicowanych pod tym względem regionów Polski (Barwiński, 2004). To, co dzisiaj określamy Podlasiem jest raczej zlepkiem różnych pojęć: geograficznych, historycznych, także etnograficznych i dlatego wyznaczenie granic tego regionu nie jest łatwe (Kaczmarek, 1980). Delimitacja Podlasia, podobnie jak wszelkich obszarów pogranicznych, wykazujących szereg cech przejściowości jest trudna (Plit, 2008). Za kolebkę Podlasia badacze zgodnie uznają obszar środkowego Bugu (Jabłonowski, 1910; Gloger, 1918; Wiśniewski, 1977; Piskozub, 1987). Rzeka Bug, pierwotnie stanowiła stymulator rozwoju regionalnego skupiając społeczności zamieszkałe po obu jej brzegach. Bug nie stanowił bariery, lecz funkcjonował jako główny szlak komunikacyjno-handlowy. Nad jego brzegami powstały najważniejsze grody - Drohiczyn i Mielnik. 
Pograniczna natura Podlasia wyrażała się w mnogości granic, które przez wieki przecinały jego obszar. Biorąc pod uwagę przynależność państwową, Podlasie należało kolejno do Rusi, Wielkiego Księstwa Litewskiego oraz I Rzeczpospolitej. W okresie zaborów region należał najpierw do Prus (część północna) i Austrii (część południowa), później z kolei do Imperium Rosyjskiego (część północna), oraz Wielkiego Księstwa Warszawskiego (część południowa) i następnie Królestwa Polskiego (część południowa). Po odzyskaniu niepodległości, w latach 1918-1939 Podlasie w całości znalazło się w granicach II RP. Był to w tym czasie region o centralnym położeniu. W latach 1939-1941 obszar Podlasia znalazł się pod okupacją ZSRS (część północna) i III Rzeszy (część południowa) a od 1941 r. do lata 1944 r. w całości znajdował się pod kontrolą III Rzeszy (Żółtowska, 2011). Po wojnie Podlasie pozostało $w$ granicach Polski, ponownie będąc regionem przygranicznym. W latach 1946-1999 granice województw na obszarze historycznego Podlasia zmieniano aż pięciokrotnie.

Region administracyjny o nazwie województwo podlaskie istniał w dwóch zasadniczo odmiennych wariantach granic. Obecne województwo jest natomiast jego kolejną, trzecią już modyfikacją. Pierwsze województwo podlaskie (określane w niniejszej pracy również jako Podlasie historyczne), utworzone zostało w roku 1513, a w latach 1566-1795, a więc przez ponad 200 lat posiadało niezmienne granice (ryc. 1).

III rozbiór Polski w 1795 r. ostatecznie przerwał spójność terytorialną Podlasia. Rzeka Bug, niegdyś regionalna oś rozwojowa, stała się odtąd granicą państwową, a dziś administracyjną. W okresie rozbiorów, w czasach Księstwa Warszawskiego powołano departament siedlecki istniejący w latach 1810-1815. W jego miejsce już w Królestwie Polskim po raz kolejny powstało województwo podlaskie funkcjonujące w latach 1816-1837. Wskutek reformy administracyjnej powołano gubernię podlaską istniejącą w latach 1837-1844, która z kolei w okresie 1867-1912, została zastąpiona przez siedlecką. Powyższe jednostki administracyjne obejmowały ten sam obszar, który stanowił fragment Podlasia historycznego położonego na południe od Bugu oraz wycinki województw brzeskiego, chełmskiego, lubelskiego, mazowieckiego i sandomierskiego z czasów I Rzeczypospolitej (Michaluk, 2013).

W 1999 r., wskutek reformy administracyjnej wśród nowo powstałych województw znalazło się województwo podlaskie w zmienionych granicach. Wydzielając tę jednostkę administracyjną uwzględniono jedynie północny fragment Podlasia historycznego. Pozostałe jego części - położone na południe od Bugu - znalazły się w województwach mazowieckim i lubelskim (ryc. 1). Nowe województwo podlaskie obejmuje natomiast obszary, które historycznie nie były związane z Podlasiem. Sejneńszczyzna i Suwalszczyzna wraz z odchodzącym od nich pasem w kierunku południowym wzdłuż wschodniej granicy Polski do Puszczy Białowieskiej należały do historycznych województw trockiego i brzeskiego. Ziemie łomżyńska, nurska i wiska stanowiły natomiast wschodnie rubieże województwa mazowieckiego. Obecny podział administracyjny jest dyskusyjny już na podstawie analizy nazw miast, które znalazły się w nowych jednostkach. Dla przykładu, Sokołów Podlaski znajduje się w województwie mazowieckim, a Biała Podlaska czy Międzyrzec Podlaski w województwie lubelskim. 


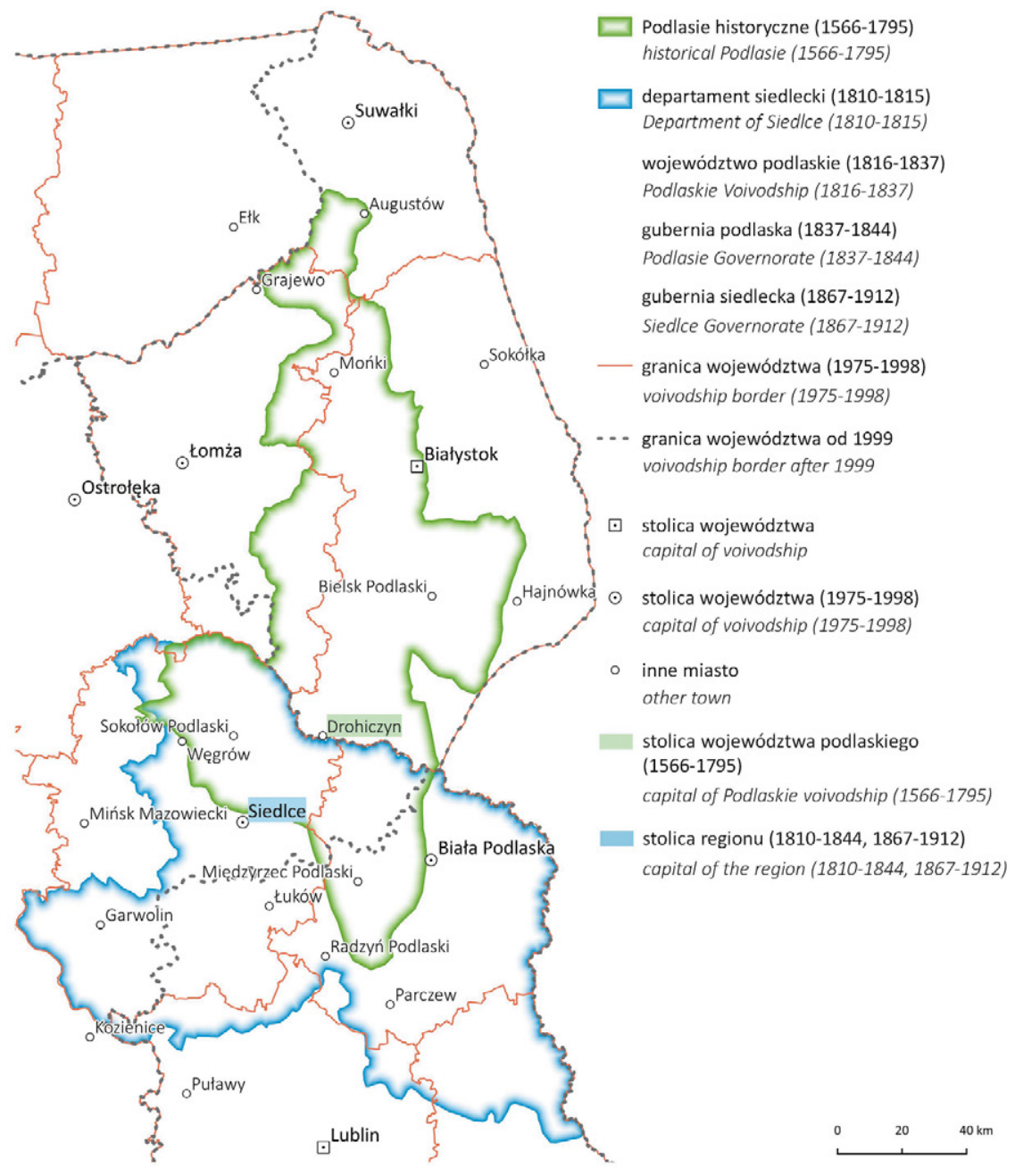

Ryc. 1. Granice historycznych i współczesnych jednostek administracyjnych na obszarze badań Borders of historical and contemporary administrative units in the research area Opracowanie własne na podstawie: Gloger, 1918; Barwiński, 2004; Żółtowska, 2011. Authors' own elaboration based on Gloger, 1918; Barwiński, 2004; Żółtowska, 2011.

\section{Postrzeganie Podlasia w różnych podziałach administracyjnych}

Percepcja regionu nazywanego Podlasiem była w przeszłości zróżnicowana i w dużej mierze zależała od obowiązującego w danym okresie podziału administracyjnego (Żółtowska, 2011; Michaluk, 2013). To odmienne postrzeganie zapoczątkowane zostało w okresie zaborów, wskutek których historyczne województwo podlaskie uległo bezpowrotnemu podziałowi. W XIX w. nazwa Podlasie zaczęła być stosowana na określenie obszarów położonych na południe od Bugu, a które nie należały do pierwszego województwa podlaskiego. Określenie Podlasie stosunkowo szybko zostało zaakceptowane, nie tylko z powodów 
administracyjnych (Michaluk, 2013). Przyczynił się do tego Kościół rzymskokatolicki. Nie bez znaczenia dla percepcji omawianego regionu jest fakt, że granice XIX-wiecznego departamentu siedleckiego, województwa podlaskiego oraz guberni podlaskiej, a następnie siedleckiej dotyczyły także diecezji janowskiej, później siedleckiej, potocznie zwanej podlaską z lat 1818-1867 i 1918-1991. Był to więc długi okres ugruntowujący w świadomości społecznej zasięg obszaru Podlasia lub nazywanego podlaskim. Istotne było również, że obszar historycznego Podlasia znajdujący się na południe od Bugu należały do Królestwa Polskiego, podczas gdy tereny po drugiej stronie rzeki znalazły się bezpośrednio w Cesarstwie Rosyjskim, w obwodzie białostockim. Obszar na północnym brzegu Bugu, choć historycznie silnie związany z Podlasiem, został w powszechnej świadomości Polaków utracony. $Z$ tego powodu gubernia podlaska stała się swego rodzaju zamiennikiem historycznego Podlasia sprzed III rozbioru Polski.

W okresie międzywojennym i później, w czasach PRL obszar Podlasia był powszechnie utożsamiany z granicami jednostek byłego Królestwa Polskiego (drugiego województwa podlaskiego i później guberni) położonymi na południowym brzegu Bugu. W okresie funkcjonowania podziału administracyjnego lat 1975-1998, częstym było stosowanie nazwy Podlasie na określenie obszaru województw bialskopodlaskiego i sieleckiego. Przykłady takiego percypowania regionalnego bez trudu można odnaleźć w literaturze (np. Kaczmarek, 1980; Podgórski, 1982; Ciechocińska, 1997). Granice tych dwu jednostek pokrywały się w znacznym stopniu z granicami historycznymi z czasów Królestwa Polskiego (ryc. 1).

Przed ostatnią reformą administracyjną Polski, autorzy opracowań naukowych, popularnonaukowych i przewodników turystycznych cechowali się brakiem zachowania spójności przestrzennej pomiędzy Podlasiem historycznym, a regionem, określanym przez nich jako Podlasie. Granice regionu często przedstawiano niedokładnie, co mogło wprowadzić czytelnika w błąd. Dla przykładu, w wydanym tuż przed reformą administracyjną Słowniku geograficzno-krajoznawczym Polski (1998) pod hasłem Podlasie czytelnik odnajdzie następujący opis „kraina historyczna leżąca między górną Narwią a Bugiem...” (s. 597). Ten krótki fragment sugeruje, że południowa granica Podlasia przebiegała wzdłuż rzeki Bug. Implikuje to percepcję regionu w oparciu o jego nieprawdziwe granice. Znacznie precyzyjniej opisany został termin Podlasie w Nowej Encyklopedii Powszechnej (1998): „kraina historyczna Polski po obu stronach środkowego Bugu i górnej Narwi..." (s. 939).

Powołanie współczesnego województwa podlaskiego w 1999 r. przyczyniło się do diametralnej zmiany w postrzeganiu obszaru nazywanego Podlasiem. W literaturze odnaleźć można wiele przejawów pojmowania tego regionu w kontekście nowopowstałej jednostki administracyjnej. Za przykład takiego percypowania może posłużyć przewodnik T. Kalińskiego oraz M. Kickiego (2011). Opracowanie przedstawia znaczny wycinek terytorium Polski: Mazowsze, łącznie z Warszawą, Warmię, Mazury, Suwalszczyznę oraz niewielki, północny wycinek historycznego Podlasia. Należy zaznaczyć, że w przypadku tego ostatniego, autorzy scharakteryzowali atrakcje turystyczne wyłącznie północnej części województwa podlaskiego, włączając Suwalszczyznę i Sejneńszczyznę. Pomimo tytułu publikacji (Warmia, Mazury, Podlasie, Północne Mazowsze), pominięto dolinę Bugu, w tym Drohiczyn, pierwszą stolicę województwa podlaskiego oraz wiele cennych kulturowo i przyrodniczo obiektów „kolebki Podlasia”. Granice historyczne Podlasia nie zostały uwzględnione. Omawiany region został zatem przedstawiony w sposób fragmentaryczny, zastosowano jego nazwę dla obszarów, które nigdy nie były związane z historycznym Podlasiem. To wycinkowe, uznaniowe ujmowanie regionu przyczynia się do kreowania specyficznej per- 
cepcji jego granic, nacechowanej brakiem spójności względem przebiegu granic krainy historycznej.

Nowy obraz Podlasia, utożsamiany z obecnym województwem podlaskim, jest utrwalany w świadomości społecznej od 1999 r. Podlasie stało się synonimem województwa podlaskiego w języku potocznym i mediach. Podejście to jest także rozpowszechniane przez środowisko naukowe (np. Bałtromiuk, 2003; Bocian, 2003a, 2003b, 2004, 2005, 2008, 2016; Czemiel-Grzybowska, 2006; Proniewski i Niedźwiecki, 2003; Plawgo i Sadowska-Snarska, 2004; Hryniewicz i Potrykowska, 2017). Co więcej, określenia Podlasie i województwo podlaskie są powszechnie stosowane jako synonimy również przez środowisko naukowe Białegostoku. Badacze z tego ośrodka akademickiego teoretycznie powinni cechować się wyższą niż ogół społeczeństwa świadomością swojego regionu zamieszkania. Może to jednak wynikać nie tyle z niewiedzy na temat braku spójności granic Podlasia historycznego i obecnego województwa, co wygody autorów chętnie stosujących te określenia w roli synonimów. Pogłębiając daną tematykę badawczą dotyczącą obecnego województwa podlaskiego, naukowcy najpewniej próbują unikać ciągłego powtarzania jego nazwy. Wynika to z dążenia do poprawnej stylistyki językowej, która nakazuje wystrzeganie się repetycji w sąsiadujących zdaniach. Jednym z synonimów dla określenia województwo podlaskie, obok terminów takich jak region czy obszar badań jest także Podlasie.

\section{Wyniki badań}

Hierarchia identyfikowania się respondentów ze szczeblami przestrzennymi na obszarze badań cechuje się występowaniem szeregu prawidłowości. W ujęciu sumarycznym, respondenci najsilniej utożsamiają się z poziomem narodowym (Polską). Średnia wartość wskazań wyniosła 4,64 (w skali 0-5). Nie zaobserwowano istotnych prawidłowości przestrzennych względem identyfikowania się z tym szczeblem (cechuje go mozaikowatość natężenia). Kolejnym szczeblem, z którym ankietowani silnie się utożsamiają jest dość szeroko zakreślony poziom lokalny. Składa się na niego relatywnie silne przywiązanie do powiatu (średnia wartość 4,38), a zwłaszcza gminy $(4,56)$ oraz miejsca zamieszkania $(4,53)$. Na uwagę zasługuje fakt wyższego utożsamiania się z poziomem lokalnym w gminach o położeniu peryferyjnym w stosunku do ośrodka wojewódzkiego czy subregionalnego. Kolejnym, trzecim w hierarchii identyfikowania się poziomem przestrzennym jest szczebel regionalny. Ankietowani silnie utożsamiają się z regionem administracyjnym utworzonym w 1999 r. (średnia wartość 4,44). Nazwa współczesnego regionu administracyjnego jest przy tym znacznie silniej identyfikowana przez respondentów w porównaniu do regionów historycznych $(3,84)$. Dawne województwa (1975-1998) cechuje niższy poziom identyfikacji $(3,49)$ wśród ankietowanych. Badani zamieszkujący gminy znajdujące się w sąsiedztwie ich stolic (Biała Podlaska, Łomża, Siedlce, Suwałki) wykazują jednak wyraźnie wyższą identyfikację z dawnymi regionami administracyjnymi.

Identyfikowanie się respondentów z regionem nieformalnym Polska Wschodnia wykazuje wyraźne zależności przestrzenne, stopniowo nasilając się w kierunku wschodniej granicy państwowej. W przypadku kilku gmin o położeniu peryferyjnym, respondenci wykazywali silniejszą identyfikację z tym nieformalnym szczeblem przestrzennym niż ze współczesnym województwem. Odwrotną prawidłowością przestrzenną cechuje się z kolei przywiązanie respondentów do poziomów ponadpaństwowych - Europy oraz 
Unii Europejskiej. Utożsamianie się ankietowanych z tymi obszarami wyraźnie wzrasta ze wschodu w kierunku zachodnim. W ujęciu regionalnym silniejsze jest także w gminach znajdujących się w pobliżu większych miast niż położonych peryferyjnie.

Stopień przywiązania do nazwy makroregionu fizycznogeograficznego jest z kolei poziomem przestrzennym, wobec którego odnotowano największe różnice pomiędzy gminami. Makroregion, którego mieszkańców cechuje najwyższe przywiązanie do jego nazwy to Pojezierze Mazurskie. Silne jest także przywiązanie do określenia Pojezierze Suwalskie. Interesującą zależność zaobserwowano natomiast wśród respondentów zamieszkujących Nizinę Południowopodlaskq̨. Najniższą identyfikacją z nim cechują się mieszkańcy gmin położonych w powiecie mińskim (Jakubów i Mrozy) w województwie mazowieckim. Ankietowani z tych gmin nie czują związku z jednostką fizycznogeograficzną, której nazwa sugeruje związek z Podlasiem. Nazwa makroregionu może budzić ich sprzeciw, znacznie silniej utożsamiają się natomiast z Mazowszem i województwem mazowieckim. W przypadku innych gmin znajdujących się we wschodniej części Niziny Południowopodlaskiej i dodatkowo położonych na historycznym Podlasiu poziom utożsamiania się z tym makroregionem jest zdecydowanie wyższy.

Poziom przywiązania respondentów do określenia Podlasie jest silnie zróżnicowany przestrzennie. W ujęciu sumarycznym identyfikacja z Podlasiem uzyskała średnią wartość 3,51 (w skali 0-5). Była ona zdecydowanie najwyższa w gminach województwa podlaskiego, choć silnie spolaryzowana (od 3,92 w gminie Puńsk do 4,68 w gminie Narewka). W przypadku niektórych gmin respondenci wykazywali porównywalny poziom identyfikacji z Podlasiem i regionem administracyjnym (województwem podlaskim). Przywiązanie do tego drugiego, sformalizowanego granicami wojewódzkimi we wszystkim przypadkach było jednak silniejsze. Chociaż granica pierwszego województwa podlaskiego nie istnieje od 1795 r., a gubernię siedlecką zniesiono w 1912 r., identyfikowanie się ankietowanych z Podlasiem w tych historycznych granicach (poza współczesnym województwem podlaskim) nadal jest relatywnie wysokie, zwłaszcza w granicach dawnego województwa bialskopodlaskiego (ryc. 2). Respondenci zamieszkali w gminach, które położone są w granicach historycznego województwa podlaskiego silniej identyfikują się z Podlasiem niż np. z dawnymi województwami, jednak słabiej niż z regionami administracyjnymi powstałymi w roku 1999. Przywiązanie do Podlasia wśród ankietowanych zamieszkałych w gminach dawnego województwa bialskopodlaskiego i siedleckiego jest znacznie wyższe w porównaniu do wyników badań przeprowadzonych w gminach województwa warmińsko-mazurskiego, które bezpośrednio przylegają do granicy województwa podlaskiego (przywiązanie do Podlasia w tych gminach jest niższe niż 3,0). Jest to zapewne efekt oddziaływania wcześniej opisanej granicy historycznej cechującej się długą trwałością, co współcześnie stanowi swoistą barierę dla tożsamości podlaskiej, pomimo sąsiedztwa regionu administracyjnego, którego nazwa nawiązuje do historycznego Podlasia.

Głównym kryterium identyfikacji respondentów z Podlasiem jest położenie badanych gmin w granicach współczesnego województwa podlaskiego (ryc. 2 i 3). Kryterium historyczne, a więc położenie badanej gminy w granicach pierwszego województwa podlaskiego jest cechą drugorzędną. Szereg gmin uwzględnionych w analizie, które historycznie nie należały do Podlasia (np. położonych w dawnym województwie suwalskim), a obecnie znajdujących się w województwie podlaskim cechują się wyższym poziomem identyfikacji z tym regionem w porównaniu do gmin, które historycznie znajdowały się na Podlasiu, lecz dziś położone są w województwach lubelskim i mazowieckim (ryc. 3). 

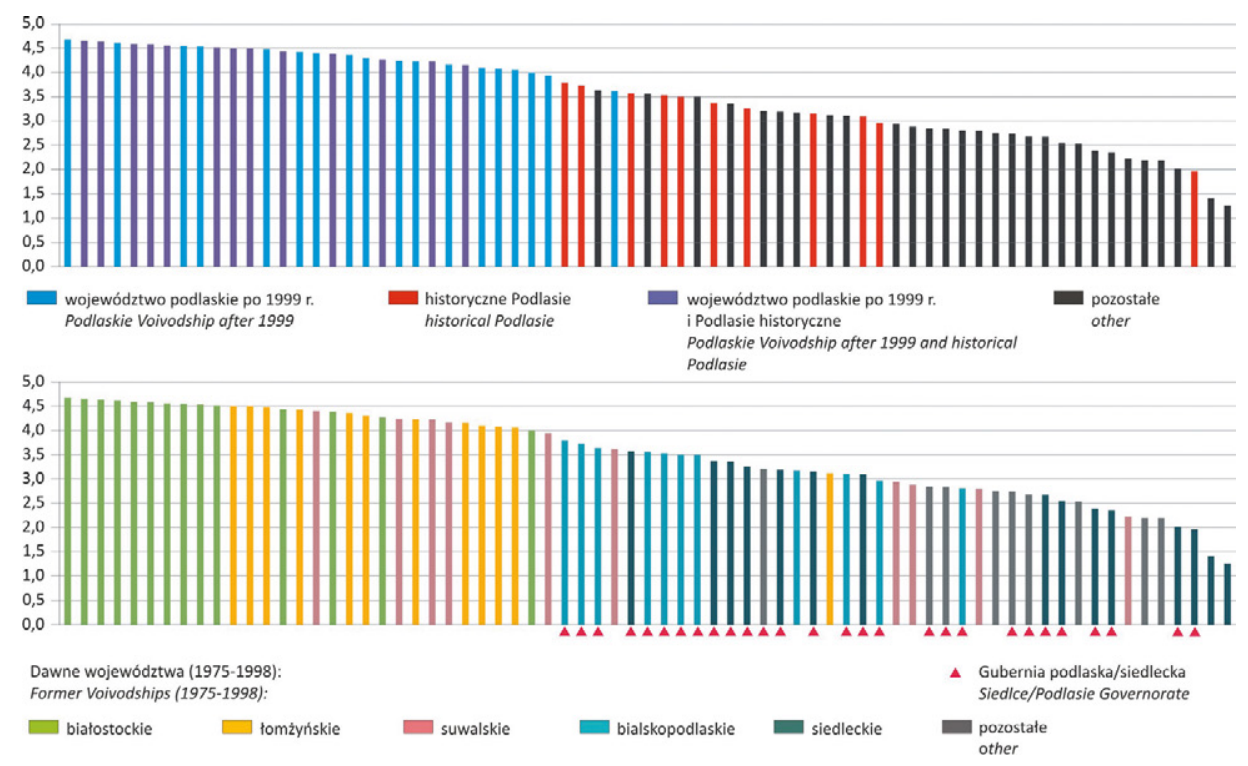

Ryc. 2. Poziom identyfikowania się respondentów z Podlasiem w badanych gminach według współczesnych i historycznych regionów administracyjnych (gminy uszeregowano malejąco w stosunku do poziomu identyfikacji z Podlasiem)

Level of respondents' identification with Podlasie in the examined communes with respect to contemporary and historical administrative regions (communes were ranked in descending order regarding identification with Podlasie)

Opracowanie własne na podstawie badań ankietowych, podobnie pozostałe ryciny. Authors' own processing of result from questionnaire surveys, like remaining figures.

Podlaska tożsamość regionalna² budowana jest w oparciu o granice współczesnego regionu administracyjnego, jednak badane zjawisko nie wykazuje jednorodnej intensywności przestrzennej (ryc. 3). Granice historyczne nadal do pewnego stopnia wykazują siłę oddziaływania, modyfikując poziom utożsamiania się z analizowanym regionem. Najsilniej z Podlasiem czują się związani ankietowani zamieszkujący dawne województwo białostockie. Słabiej utożsamiają się z Podlasiem respondenci zamieszkujący część województwa podlaskiego, która dawniej stanowiła fragment województwa suwalskiego. Najbardziej zróżnicowany jest obszar dawnego województwa łomżyńskiego. Respondentów z obszarów dawnych województw łomżyńskiego i suwalskiego cechował nie tylko wyższy brak zdecydowania niż w przypadku dawnego województwa białostockiego, ale również istnienie odmiennych tożsamości regionalnych i lokalnych (badanych za pomocą osobnego pytania w kwestionariuszu) wynikających z uwarunkowań historycznych. W dawnym województwie suwalskim były to przywiązanie do Suwalszczyzny i Sejneńszczyzny. W województwie łomżyńskim natomiast badanie kwestionariuszowe wykazało niewielkie utożsamianie się respondentów z Mazowszem i Kurpiami.

Wpływ ostatniej reformy administracyjnej na charakter i intensywność tożsamości regionalnej ankietowanych mieszkańców północno-wschodniej Polski potwierdza

\footnotetext{
2 Na podstawie pytania: Czy mieszka Pan/Pani na Podlasiu?
} 


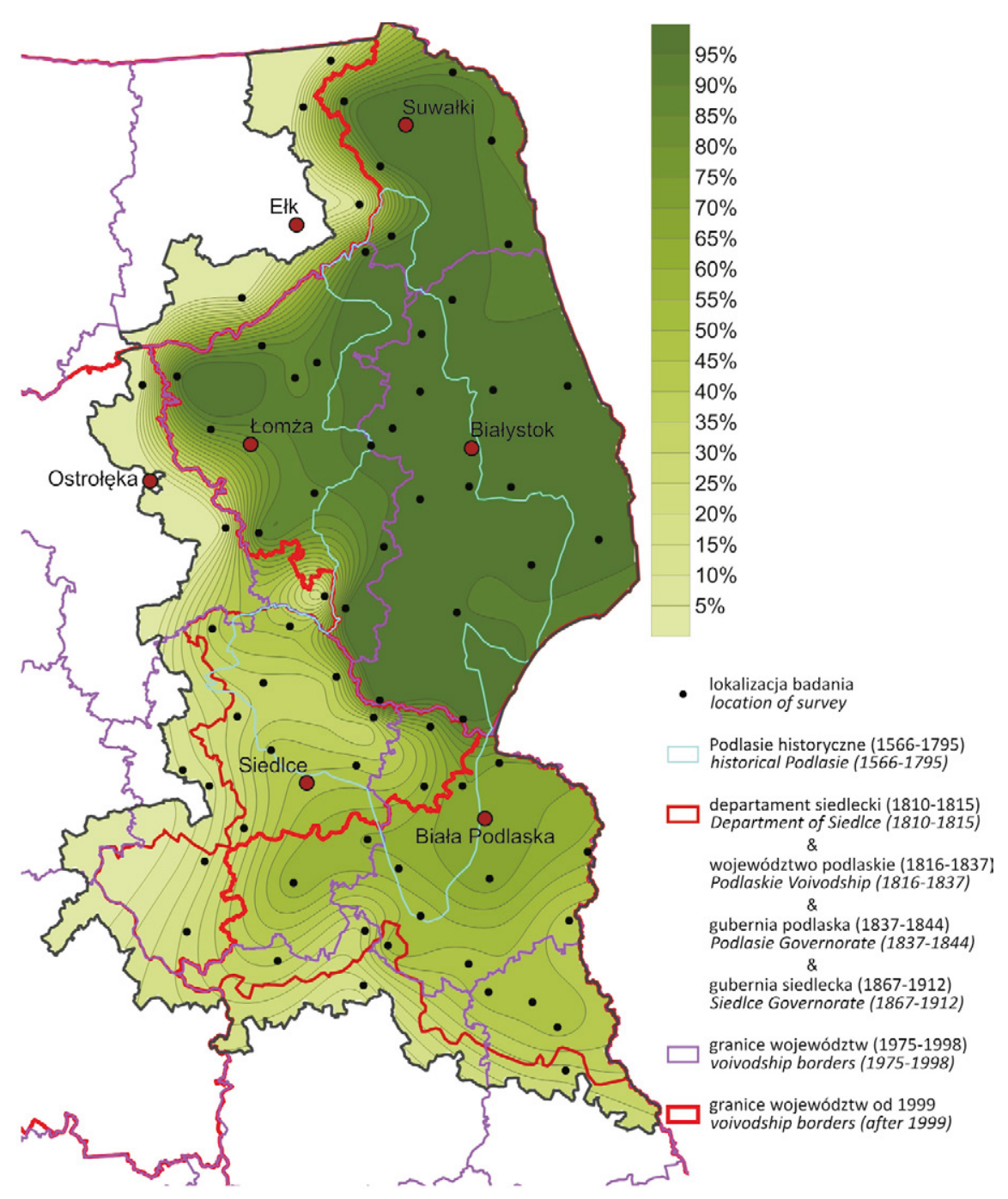

Ryc. 3. Syntetyczny wskaźnik odpowiedzi na pytanie: Czy mieszka Pan/Pani na Podlasiu? Synthetic indicator of responses to the question: Do you live in Podlasie?

ich relatywnie niskie przywiązanie do dawnych województw³ (z lat 1975-1998) (ryc. 4). Najniższym przywiązaniem do dawnego podziału regionalnego cechują się mieszkańcy województwa białostockiego, na obszarze którego wskaźnik ten cechuje względna jednorodność. Miasto Białystok nie straciło wskutek reformy administracyjnej funkcji miasta wojewódzkiego, a jego znaczenie w aspekcie funkcjonalno-przestrzennym de facto wzrosło od 1999 r. Białystok jako stolica województwa podlaskiego wpisuje się także w tożsamość regionalną mieszkańców byłego województwa białostockiego, którzy jednocześnie

\footnotetext{
${ }_{3}$ Na podstawie pytania: Czy chciałby/chciałaby Pan/Pani przywrócenia dawnego województwa z lat 1975-1998?
} 
najsilniej utożsamiają się z Podlasiem. Przywrócenie dawnego województwa spowodowałoby nie tylko spadek rangi Białegostoku. Likwidacja województwa podlaskiego byłaby niezgodna z tożsamością regionalną jego mieszkańców, pobudzając dychotomię toponimów między regionem administracyjnym i historycznym.

Na pozostałym obszarze badań przywiązanie do dawnych województw (1975-1998) jest wśród respondentów relatywnie niskie. Zauważalna jest jednak wyraźnie wyższa chęć przywrócenia tych regionów administracyjnych wśród badanych zamieszkujących gminy zlokalizowane w pobliżu ich stolic (Biała Podlaska, Siedlce, Łomża, Suwałki). Wzrost omawianego wskaźnika od peryferii dawnych województw w kierunku ich głównych miast jest ewidentny (ryc. 4). Ta zależność wynika z większego przywiązania mieszkańców gmin ościennych do dawnego miasta wojewódzkiego w aspekcie funkcjonalno-przestrzennym (edukacja, rynek pracy i związane z nimi migracje wahadłowe do miast - czynniki budujące przywiązanie). Przywrócenie dawnych województw i ich stolic oznaczałoby poniekąd wzrost utraconego wskutek ostatniej reformy administracyjnej prestiżu miasta stołecznego regionu. Silniejsze wśród ankietowanych przywiązanie do dawnych województw bialskopodlaskiego, łomżyńskiego, siedleckiego i suwalskiego niż białostockiego może, do pewnego stopnia, wynikać ze sprzeciwu wobec nazwy obecnego województwa. Mieszkańcy gmin położonych w dawnym województwie łomżyńskim, które należały do historycznego Podlasia, cechują się wyraźnie niższym poparciem dla jego przywrócenia (ryc. 4.). Jako mieszkańcy historycznego Podlasia mogą silniej identyfikować się z województwem podlaskim niż łomżyńskim. W gminach położonych wokół Łomży sytuacja jest odwrotna, część badanych nie utożsamia się z Podlasiem i województwem podlaskim (gminy te nie są położone na historycznym Podlasiu), silniej więc utożsamiają się z dawnym województwem (oraz prawdopodobnie miastem, od którego pochodzi nazwa regionu). Wyższa wartość omawianego wskaźnika może jednak wynikać nie tyle z tożsamości respondentów kolidującej z nazwą i terytorium nowych województw, ile z lokalnego patriotyzmu lub sentymentu za utraconym województwem.

Na podstawie przeprowadzonych badań można stwierdzić, że granice współczesnego województwa podlaskiego odcisnęły wyraźne piętno w postrzeganiu regionu historycznego i administracyjnego. Najczęściej bowiem respondenci zamieszkujący ten region administracyjny utożsamiają województwo podlaskie i Podlasie jako jeden obszar. Określenia te (co wcześniej omówiono) funkcjonują jako swego rodzaju synonimy - stosowane dość powszechnie - nie tylko wśród mieszkańców województwa podlaskiego. Podobna prawidłowość dotyczy także innych regionów, jak np. synonimiczne stosowanie nazw województwo mazowieckie i Mazowsze, województwo lubelskie i Lubelszczyzna, itd. Powszechność tego zjawiska z pewnością przyczyniła się do powstania konfuzji podczas udzielania odpowiedzi na pytania zawarte w kwestionariuszu ankiety. Wyrazem synonimicznego stosowania nazw regionów jest dość równomierne natężenie tego wskaźnika na całym obszarze badań i relatywnie niewielka polaryzacja przestrzenna (ryc. 5). Wartość omawianego wskaźnika jest niższa w gminach, które należały do historycznego Podlasia, a obecnie znajdują się w województwie lubelskim i mazowieckim. W gminach tych utożsamianie z Podlasiem jest relatywnie wysokie. Podobnie jest w przypadku respondentów, którzy zamieszkują gminy poza historycznym Podlasiem, lecz położonych we wschodniej części regionów Królestwa Polskiego (guberni podlaskiej i siedleckiej, patrz ryc. 1.). Jest to przesłanka, aby stwierdzić istnienie w świadomości mieszkańców tych gmin przywiązania do historycznego Podlasia. Wskaźnik ten jest niższy właśnie w powyższych grani- 
cach historycznych, gdyż ankietowani zamieszkujący położone tam gminy identyfikują się z Podlasiem, a nie z województwem podlaskim, stąd silniej niż na pozostałym obszarze badań rozgraniczają odmienne znaczenie tych określeń.

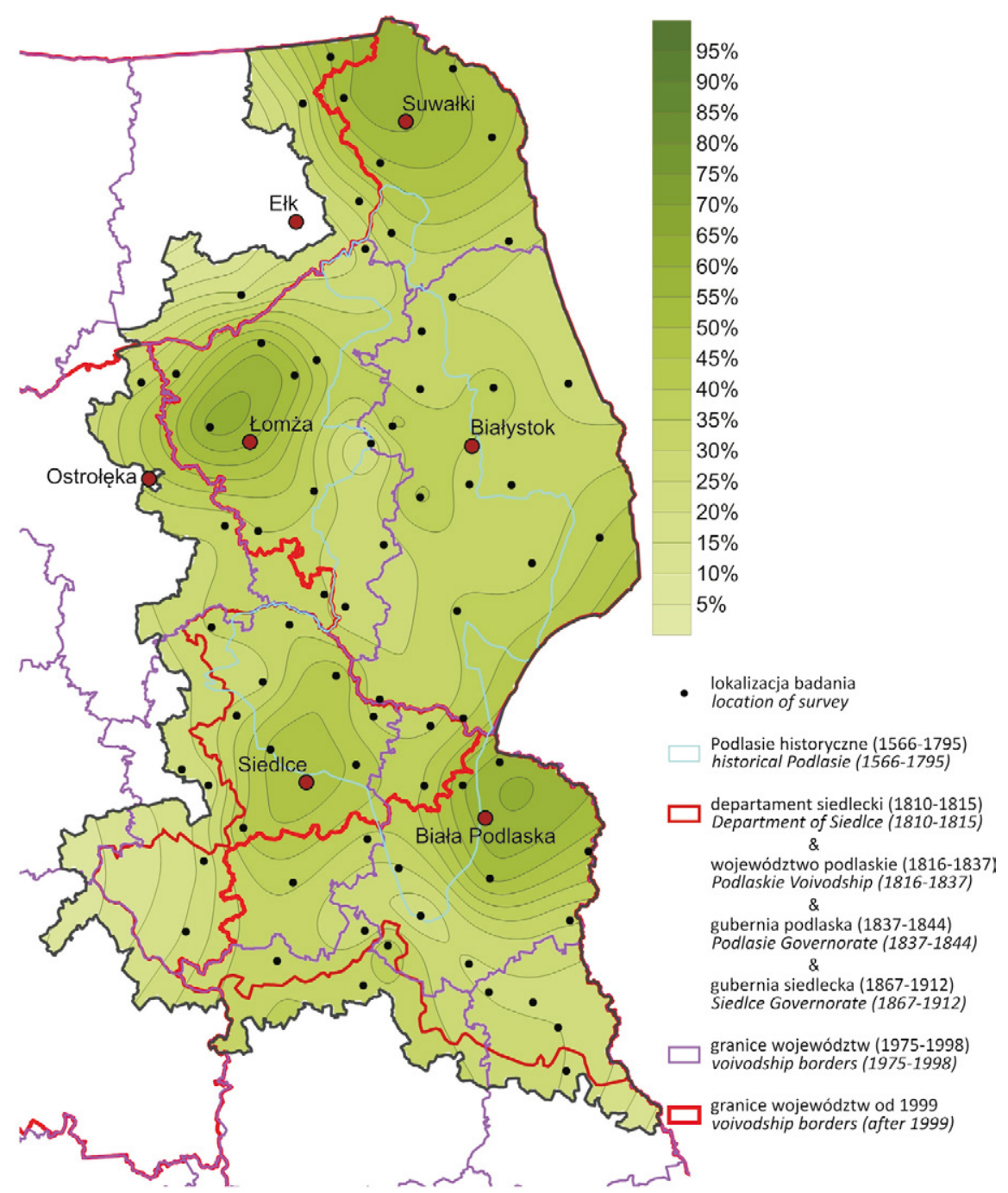

Ryc. 4. Syntetyczny wskaźnik odpowiedzi na pytanie: Czy chciałby/chciałaby Pan/Pani przywrócenia dawnego województwa z lat 1975-1998?

Synthetic indicator of responses to the question: Would you like to restore the former voivodship from the years 1975-1998? 


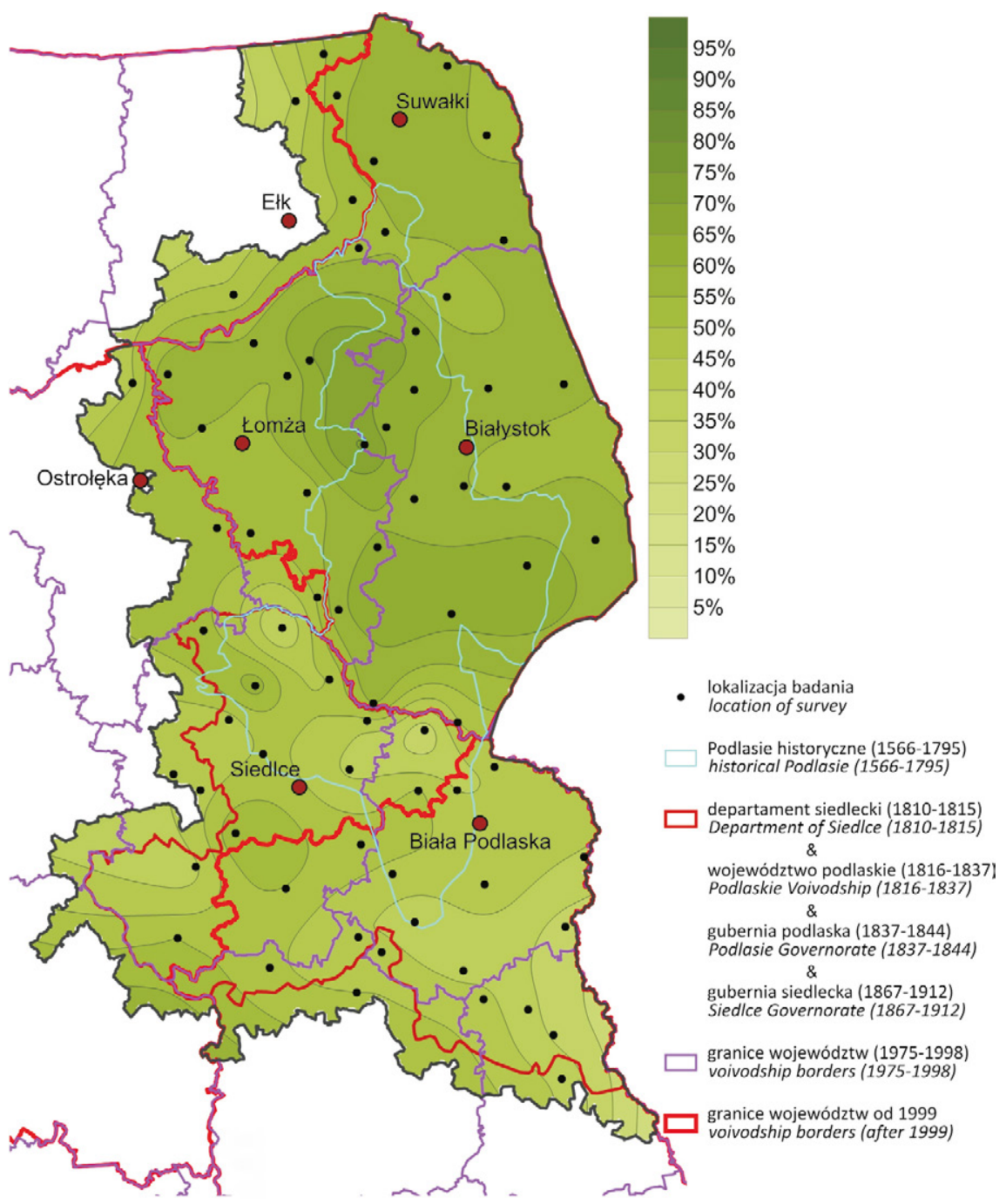

Ryc. 5. Syntetyczny wskaźnik odpowiedzi na pytanie: Czy uważa Pan/Pani, że województwo podlaskie i Podlasie obejmujq ten sam obszar?

Synthetic indicator of responses to the question: Do you consider that Podlaskie Voivodship and Podlasie cover the same area?

\section{Podsumowanie}

Zarówno samo poczucie tożsamości jak i jej badanie jest złożonym zagadnieniem. Na przywiązanie do danego obszaru można spojrzeć z wielu perspektyw m.in. geograficznej (przestrzennej), psychologicznej, historycznej, socjologicznej, ekonomicznej, politologicznej itp. (por. Szczepański i Śliz, 2018). Wymiary te silnie wpływają na formowanie się poczucia tożsamości regionalnej, które może ulegać przemianom (osłabieniu lub wzmoc- 
nieniu) na skutek różnego rodzaju doświadczeń czy wydarzeń, zarówno tych historycznych (np. tzw. bieżeństwo w 1915 r. ${ }^{4}$ ) jak i współczesnych. Na konstruowanie poczucia tożsamości regionalnej wpływają również czynniki przestrzenne w postaci narzucenia granic regionów administracyjnych i związanego z nimi utrwalania przynależności do danego regionu.

Tożsamość regionalna ludności zamieszkującej badany obszar budowana jest przede wszystkim w oparciu o współczesne granice regionów administracyjnych, co zapewne jest wynikiem nieświadomego używania pojęcia Podlasie do określenia zarówno regionu administracyjnego jak historycznego. Budowana w ten sposób (podlaska) tożsamość regionalna obejmuje tereny, które nigdy nie były związane z Podlasiem (ani w ujęciu historycznym, ani w ujęciu jednostek fizycznogeograficznych), np. Suwalszczyzna czy Kurpie. Jednak nowe granice administracyjne narzuciły podświadomie utożsamianie się z regionem administracyjnym na równi z regionem historycznym i kulturowym. Najwyższy poziom tożsamości regionalnej obejmuje dawne województwo białostockie, tworząc rdzeń podlaskości. Natomiast najmniejszy stopień utożsamiania się z Podlasiem występuje w zachodniej części województwa podlaskiego, co przejawia się również najwyższym sentymentem do dawnego województwa łomżyńskiego. Widoczny jest wysoki stopień domknięcia podlaskiej tożsamości regionalnej w granicach obecnego województwa. Dostrzegalna jest przy tym trwałość niektórych granic historycznych np. dawnej granicy zaboru rosyjskiego i pruskiego.

Zauważalne jest również zjawisko silniejszego identyfikowania się badanych osób z poziomem krajowym (narodowym) i lokalnym (małe ojczyzny) niż z poziomem regionalnym. Szczebel regionalny stanowi dopiero trzeci poziom $w$ hierarchii poczucia tożsamości z danym obszarem. Z jednej strony niższy stopień utożsamiania się z regionem można traktować jako wynik braku stałości granic administracyjnych, przez pryzmat których jak wykazały badania - mieszkańcy postrzegają swój region. Z drugiej strony istotną rolę odgrywa peryferyjne położenie regionu, przez co na pierwszy plan wysuwa się przywiązanie do poziomu narodowego, jako chęć podkreślenia przynależności do danego państwa, mimo (a może raczej na skutek) położenia z dala od centrum życia gospodarczego kraju.

Interesującą prawidłowością jest wyraźnie wyższa tożsamość lokalna w gminach o położeniu peryferyjnym w stosunku do ośrodków wojewódzkich czy subregionalnych (w tym gmin leżących przy granicy państwowej), co może wynikać z braku ugruntowanych powiązań funkcjonalnych i wyższej izolacji przestrzennej. Zróżnicowanie wyznaniowe nie ma większego wpływu na poziom utożsamiania się z regionem, podobnie jak przynależność etniczna, z jednym tylko wyjątkiem. Grupa osób, która nie podała żadnej przynależności narodowościowej i określająca siebie jako „tutejsi” (w niektórych gminach odsetek ten był dość wysoki, sięgający 30\%) wykazuje niski poziom tożsamości na poziomie narodowym i regionalnym, natomiast wysoki wyłącznie na poziomie lokalnym.

Tożsamość podlaska ogranicza się do obszaru województwa podlaskiego. Sugeruje to postrzeganie jej poprzez pryzmat ostatniego podziału administracyjnego. Jest to tym bardziej warte podkreślenia, że mamy tu do czynienia z obszarem zróżnicowanym pod względem wyznaniowym, kulturowym, również językowym, a mimo to w świadomości tak zróżnicowanej społeczności postrzeganie regionu jako jednostki administracyjnej jest podobne.

\footnotetext{
${ }^{4}$ Masowa ewakuacja (wysiedlenie) ludności z zachodnich guberni Imperium Rosyjskiego w 1915 r. Dotyczyła przeważnie ludności wyznania prawosławnego i objęła głównie gubernię grodzieńską. Szerzej o bieżeństwie w: Prymaka-Oniszk, 2016.
} 


\section{Piśmiennictwo}

Bałtromiuk A., 2003, Obszary wiejskie województwa podlaskiego w perspektywie integracji z UE, [w:] A.F. Bocian (red.), Podlasie granicq Europy, Wydawnictwo Uniwersytetu w Białymstoku, Białystok s. 115-130.

Barwiński M., 2004, Podlasie jako pogranicze narodowościowo-wyznaniowe, Wydawnictwo Uniwersytetu Łódzkiego, Łódź.

Bocian A.F. (red.), 2003a, Podlasie granica Europy, Wydawnictwo Uniwersytetu w Białymstoku, Białystok.

Bocian A.F. (red.), 2004, Podlasie - wizja rozwoju, Fundacja Promocji Rozwoju Podlasia, Białystok.

Bocian A.F. (red.), 2005, Podlasie a procesy integracji, Wydawnictwo Uniwersytetu w Białymstoku, Białystok.

Bocian A.F. (red.), 2008, Podlasie - dwie dekady transformacji, Wydawnictwo Uniwersytetu w Białymstoku, Białystok.

Bocian A.F., 2003b, Podlasie - nowe możliwości i szanse, [w:] A.F. Bocian (red.), Podlasie granica Europy, Wydawnictwo Uniwersytetu w Białymstoku, Białystok, s. 18-31.

Bocian A.F., Perło D., Piątkowski P. (red.), 2016, Podlasie - wizje przemian i rozwoju, Fundacja Promocji Rozwoju Podlasia, Białystok.

Bokszański Z., 1989, Tożsamość, interakcja, grupa. Tożsamość jednostki w perspektywie teorii socjologicznej, Wydawnictwo Uniwersytetu Łódzkiego, Łódź.

Bokszański Z., 2005, Tożsamości zbiorowe, Wydawnictwo Naukowe PWN, Warszawa.

Chojnicki Z., 1996, Region w ujęciu geograficzno-systemowym, [w:] T. Czyż (red.), Podstawy regionalizacji geograficznej, Bogucki Wydawnictwo Naukowe, Poznań, s. 7-43.

Ciechocińska M. (red.), 1997, Podlasie w warunkach transformacji systemowej lat 90. Polsko-Białoruskie seminarium naukowe pt.,, Miasta przygraniczne Polski i Białorusi w warunkach liberalizacji i rozwoju demokracji", Polskie Towarzystwo Geograficzne, Komisja Zastosowań Geografii, Wyższa Szkoła Rolniczo-Pedagogiczna w Siedlcach, Siedlce.

Czemiel-Grzybowska W., 2006, Wpływ funduszy przedakcesyjnych na funkcjonowanie małych i średnich przedsiębiorstw w regionie podlaski, Rozprawy Naukowe Seria I, 4, Wyższa Szkoła Finansów i Zarządzania w Białymstoku, Białystok.

Dziekanowska M., 2015, Poczucie tożsamości regionalnej mieszkańców Lubelszczyzny, Wydawnictwo Uniwersytetu Marii Curie-Skłodowskiej, Lublin.

Erikson E., 1974, Identity. Youth and Crisis, Faber \& Faber, London.

Geiss I., 1996, Lud, terytorium, naród, państwo, [w:] M. Wojciechowski, R. Schattkowsky (red.), Regiony pograniczne Europy Środkowo-Wschodniej w XVI-XX wieku. Społeczeństwo - gospodarka - polityka, UMK, Toruń, s. 23-49.

Giddens A., 1985, The Nation-state and Violence, Polity Press, Cambridge.

Giddens A., 2005, Socjologia, PWN, Warszawa

Gloger Z., 1918, Opis historyczny Podlasia i ziemi Chełmskiej, [w:] W obronie ziemi. Z przedmowq Zygmunta Chrzanowskiego. Z dwiema mapami, Skład Główny w Biurze Pracy Społecznej, Warszawa, s. 7-18.

Hartshorne R., 1936, Suggestions on the terminology of political boundaries, Annals of the Association of American Geographers, 22.

Hryniewicz J., Potrykowska A. (red.), 2017, Sytuacja demograficzna Podlasia jako wyzwanie dla polityki społecznej i gospodarczej, Rządowa Rada Ludnościowa, Warszawa.

Huntington S., 1998, Zderzenie cywilizacji i nowy kształt ładu światowego, Muza SA, Warszawa. 
Jabłonowski A., 1910, Podlasie, cz. 3, [w:] Polska XVI w. pod względem geograficzno-statystycznym, tom VI, [w:] Źródła dziejowe, 17, Gebethner i Wolff, Warszawa, s. 257-258.

Jordan T.G., 1978, Perceptual regions in Texas, Geographic Review, 68, 3, s. 293-307.

Kaczmarek J., 1980, Na Podlasiu. Gawędy krajoznawcze, Wydawnictwa Szkolne i Pedagogiczne, Warszawa.

Kaliński T., Kicki M. (red.), 2011, Warmia, Mazury, Podlasie, Północne Mazowsze, Carta Blanca Grupa Wydawnicza PWN, Warszawa.

Knight D.B., 1982, Identity and Territory: Geographical Perspectives on Nationalism and Regionalism, Annals of the Association of American Geographers, 72, 4, s. 514-531.

Kołodziejski J., 1991, Podział terytorialny (administracyjny) kraju jako problem organizacji przestrzennej społeczeństwa, gospodarki i państwa, [w:] Koncepcje regionalnej organizacji kraju, Biuletyn Komitetu Przestrzennego Zagospodarowania Kraju PAN, 156, s. 7-34.

Komornicki T., 2010, Rola wymiany towarowej ze wschodnimi sq̨siadami Polski w gospodarce lokalnej, Prace Komisji Geografii Przemysłu, 15, Warszawa-Kraków, s. 105-116.

Łukowski W., 2002, Społeczne tworzenie ojczyzn. Studium tożsamości mieszkańców Mazur. Wydawnictwo Naukowe Scholar, Warszawa.

Malicki K., 2010, Pamięć zbiorowa jako element tożsamości regionalnej na przykładzie regionu podkarpackiego, [w:] Z. Rykiel (red.), Tożsamość terytorialna w różnych skalach przestrzennych, Wydawnictwo Uniwersytetu Rzeszowskiego, Rzeszów, s. 124-134.

Matykowski R., 1996, Rola świadomości regionalnej w kształtowaniu granic regionu poznańskiego, [w:] T. Czyż (red.), Podstawy regionalizacji geograficznej, Bogucki Wydawnictwo Naukowe, Poznań, s. 127-140.

Matykowski R., 2017, Zbiorowości społeczno-przestrzenne i ich zwiqzzki z terytorium: formy i czynniki regionalizmu w Polsce, Bogucki Wydawnictwo Naukowe, Poznań.

Michaluk D., 2013, Granice województwa podlaskiego i postrzeganie obszaru Podlasia w latach 1513-2013, [w:] Podlasie nadbużańskie. 500-lecie województwa podlaskiego, Muzeum Rolnictwa im. ks. Krzysztofa Kluka Instytucja Kultury Województwa Podlaskiego, Urząd Marszałkowski Województwa Podlaskiego Departament Kultury i Dziedzictwa Narodowego, Białystok, s. 169-191.

Miszczuk A., 2003, Regionalizacja administracyjna III Rzeczpospolitej. Koncepcje teoretyczne a rzeczywistość, Wydawnictwo Uniwersytetu Marii Curie-Skłodowskiej, Lublin.

Nowa Encyklopedia Powszechna, 1998, t. 4, Wydawnictwo Naukowe PWN, Warszawa.

Nowak K., 2018, Wpływ przebiegu granic województw na tożsamość regionalnq oraz postrzeganie regionów Małopolski i Ślqqska, Studia Regionalne i Lokalne, 1, 71, s. 62-81.

Otremba T., 1997, Wyżyna Polska, Regnum, Gdańsk.

Palmowski T. (red.), 2007, Pogranicze polsko-rosyjskie. Problemy współpracy transgranicznej z Obwodem Kaliningradzkim, Wydawnictwo Bernardinum, Gdynia-Pelplin.

Pezzini M., 2000, Territorial Governance: Main issues and Trends in OECD countries, [w:] Territorial Development Policies and Issues, OECD, Paris, s. 197-207.

Piskozub A., 1987, Dziedzictwo polskiej przestrzeni: geograficzno-historyczne podstawy struktur przestrzennych ziem polskich, Zakład Narodowy im. Ossolińskich, Wrocław.

Plawgo B., Sadowska-Snarska C., 2004, Rynek pracy w regionie podlaskim - stan i perspektywy, Wydawnictwo Wyższej Szkoły ekonomicznej w Białymstoku, Białystok.

Plit F., 2008: Województwo podlaskie - region pogranicza, [w:] Współczesne problemy badawcze geografii polskiej - geografia człowieka, (red.) D. Świątek, M. Bednarek, P. Siłka, Dokumentacja 
Geograficzna, 36 Instytut Geografii i Przestrzennego Zagospodarowania PAN, Polskie Towarzystwo Geograficzne, Warszawa, s. 7-14.

Podgórski M., 1982, Traktem bitym przez Podlasie, Krajowa Agencja Wydawnicza, Lublin.

Pollice F., 2003, The role of territorial identity in local development processes, Proceedings of the Conference - The Cultural Turn in Geography, Landscape Construction and Cultural Identity, University of Trieste, Trieste, s. 107-117.

Powęska H., 2011, Struktura towarowa handlu przygranicznego na pograniczu polsko-ukraińskim, Roczniki Naukowe Stowarzyszenia Ekonomistów Rolnictwa i Agrobiznesu, 13, 2 s. 371-376.

Prawelska-Skrzypek G., 1996, Świadomość regionalna w Małopolsce - studium empiryczne [w:] G. Prawelska-Skrzypek (red.), Małopolska regionalna wspólnota interesów, Wyższa Szkoła Biznesu, Nowy Sącz, s. 41-59.

Proniewski M., Niedźwiecki A., 2003, Efekty restrukturyzacyjne wspólnego rynku jako czynnik rozwoju Podlasia, [w:] A.F. Bocian (red.), Podlasie granica Europy, Wydawnictwo Uniwersytetu w Białymstoku, Białystok, s. 72-80.

Prymaka-Oniszk A., 2016, Bieżeństwo 1915. Zapomniani uchodźcy, Wydawnictwo Czarne, Wołowiec.

Rak G., 2013, Percepcja przestrzeni regionalnej, rozprawa doktorska, Politechnika Opolska, Wydział Wychowania Fizycznego i Fizjoterapii, Instytut Turystyki i Rekreacji, Katedra Turystyki i Promocji Zdrowia.

Ratti R., 1993, How can existing barriers and burden effects be overcome? A theoretical approach, [w:] R. Cappellin, P.J. Batey (red.), Regional Networks, Border Regions and European Integration, Pion, London, s. 60-69.

Rykiel Z., 1985, Badania świadomości regionalnej - przykład regionu katowickiego, Przegląd Geograficzny, 57, 1-2, s. 37-58.

Rykiel Z., 1999, Przemiany struktury społeczno-przestrzennej miasta polskiego a świadomość terytorialna jego mieszkańców, Prace Geograficzne, 170, Instytut Geografii i Przestrzennego Zagospodarowania PAN, Warszawa.

Rykiel Z., 2010, Tożsamość terytorialna jako uczestnictwo w kulturze, [w:] Z. Rykiel (red.), Tożsamość terytorialna w różnych skalach przestrzennych, Wydawnictwo Uniwersytetu Rzeszowskiego, Rzeszów, s. 17-29.

Rykiel Z. 2009, Podkarpacie jako region - podstawy teoretyczne, [w:] A. Tuziak, B. Tuziak (red.), Regionalny wymiar procesów transformacyjnych, Scholar, Warszawa, s. 13-28.

Rykiel Z., 2016, Tożsamość terytorialna, nacjonalizm i kreacja tożsamości lokalnej, [w:] M. Wójcicka, M. Dziekanowska (red.), Współczesne kreacje tożsamości społeczno-kulturowych, Uniwersytet Marii Curie-Skłodowskiej, Lublin, s. 9-20.

Schattkowsky R., 1996, Region między Wschodem a Zachodem. Regionalizacja i władza w Europie Środkowo-Wschodniej, [w:] M. Wojciechowski, R. Schattkowsky (red.), Regiony pograniczne Europy Środkowo-Wschodniej w XVI-XX wieku. Społeczeństwo- gospodarka- polityka, Uniwersytet Mikołaja Kopernika, Toruń, s. 7-22.

Schmidt J., 1997, Stereotyp i granica. Pogranicze zaborów w mentalności współczesnych Wielkopolan, Wydawnictwo „ECO”, Międzychód.

Scott J.W., 2018, Border politics in Central Europe: Hungary and the role of national scale and nation-building, Geographia Polonica, 91, 1, s. 17-32.

Słownik geograficzno-krajoznawczy Polski, 1998, PWN, Warszawa.

Sobczyński M., 1984, Niezmienność dawnych granic politycznych na obszarze Polski, Acta Universitatis Lodziensis, Folia Geographica, 3, s. 119-137. 
Solarz M., 2014, Trwałość granic politycznych państwa polskiego w latach 1569/1667-2014, Prace i Studia Geograficzne, 54, s. 125-138.

Szczepański M.S., Śliz A., 2018, Kim jestem? Identyfikacje i tożsamości społeczne. Przypadek Górnego Śląska, Nauka, 1, s. 129-142.

Szczepkowski J., 1991, Projekt podziału administracyjnego Polski, [w:] Koncepcje regionalnej organizacji kraju, Biuletyn Komitetu Przestrzennego Zagospodarowania Kraju PAN, 156, s. 117-132. Szyfer A., 1996, Warmiacy. Studium tożsamości, Kantor Wydawniczy SAWW, Poznań.

Veneri P., 2011, Territorial Identity in Italian NUTS-3 Regions, II Capitale Territoriale: scenari quali-quantitativi di superamento della crisi economica e finanziaria per le province italiane, Dipartimento di Economia - Università Politecnica del le Marche, Ancona.

Weigend G.G., 1950, Effects of boundary changes in the South Tyrol, Geographical Review, 40, s. 364-375.

Whebell C.F.J., 1973, A model of territorial separatism, Proceedings, Association of American Geographers, 5, s. 295-298.

Wiśniewski J., 1977, Osadnictwo wschodniej Białostocczyzny, Acta Baltico-Slavica, 11, s. 7-80.

Zaborowski Ł., 2013, Podział kraju na województwa. Próba obiektywizacji, Wydawnictwo Naukowe Scholar, Warszawa.

Żółtowska J.E., 2011, Podziały polityczno-administracyjne na ziemi podlaskiej w ciqgu tysiqclecia, Roczniki Nauk Społecznych, 39, 3, s. 235-269.

\section{Summary}

In the (late $16^{\text {th }}$ - to late $18^{\text {th }}$ - century) times of the First Republic of Poland, administrative division was mainly determined by Catholic Church structures and the borders of historical regions. In contrast, the period of the People's Republic of Poland (in essence from World War II's end through to 1989) saw primarily economic concepts of administrative division put in place. The onset of the era of Poland's political transformation post-1989 thus minded scientists to attend to the need for a new territorial division underpinned by rational and objective assumptions. Regional identity- as a relevant aspect of historical conditioning - was certainly taken account of, as an important criterion vis-à-vis administrative division. R. Schattkowsky (1996), I. Geiss (1996) and T. Otremba (1997) all stressed the importance of historical conditioning to the transforming Central and Eastern European Countries. However, Poland's latest administrative reform did not take much account of historical conditions as numerous borders of the (16) new voivodships were put in place. Lack of consistency can even be observed in the nomenclature of these newly-established administrative units, with a mixture of names deriving from historical regions and others simply referring to capital cities. In no way are the borders of the contemporary voivodships consistent with those of historical Polish regions (Miszczuk 2003; Zaborowski 2013; Nowak 2018.)

The current administrative division of Poland is thus largely based upon imposed borders actually dividing previously-coherent regions. When set against those of the former regions, the borders of the new administrative units are seen to be characterised by a significant lack of harmony - all the more so given that the relict borders are still found to be apparent in public awareness, thanks to historical conditioning. 
The research topic presented here thus arises from what is alluded to above, i.e. the dichotomy between the names given (or toponymy applied) to voivodships as a result of the administrative reform of 1999 and the names of historical regions. This article presents selected results of empirical research conducted by using a questionnaire among the inhabitants of 71 communes (units of local-government administration) in north-eastern Poland. The main aim was to examine the impact of recent administrative reform on regional identity in the studied communities, with particular emphasis placed on Podlasie as a border region displaying a high degree of linguistic, cultural and religious diversity. The work determined the extent to which respondents identified with different levels, tiers or categories of spatial division, in fact revealing how respondents identify themselves more with the national (domestic) and local (small-homeland) level than with the regional level, which was only ranked third in the hierarchy of identification with a given area. Nevertheless, the regional identity of the population living in north-east Poland is built primarily upon the contemporary borders of administrative regions. 